\title{
Diatoms modify the relationship between dissolved silicon and bicarbonate in impounded rivers
}

\author{
Baoli WANG,${ }^{1 *}$ Cong-Qiang LIU, ${ }^{1}$ Fushun WANG, ${ }^{2}$ Benjamin CHETELAT, ${ }^{1}$ Stephen C. MABERLY ${ }^{3}$ \\ ${ }^{1}$ State Key Laboratory of Environmental Geochemistry, Institute of Geochemistry, Chinese Academy of Sciences, Guanshui Road 46, \\ 550002 Guiyang; ${ }^{2}$ Institute of Applied Radiation, School of Environmental and Chemical Engineering, Shanghai University, Shangda \\ Road 99, 201800 Shanghai, China; ${ }^{3}$ Centre for Ecology and Hydrology, Lancaster Environment Centre, Library Avenue, LA1 4AP \\ Bailrigg, UK \\ *Corresponding author: baoliwang@163.com
}

\begin{abstract}
In order to investigate the relationship between dissolved silicon (DSi) and bicarbonate $\left(\mathrm{HCO}_{3}^{-}\right)$, we analysed water samples from the main Changjiang channel and its main tributaries in August 2006 and, during 2007-2009, the contrasting tributaries Wujiang (WJ) - mainly dominated by carbonate weathering, and Ganjiang - mainly dominated by silicate weathering. The $\mathrm{DSi}: \mathrm{HCO}_{3}{ }^{-}$ratio ranged from 0 to 0.67 , which is in agreement with mixing between the weathering of carbonate or silicate. $A$ negative correlation between DSi and $\mathrm{HCO}_{3}^{-}$was observed and interpreted as the imprint of regional geology on water chemistry. This relationship and the $\mathrm{DSi}: \mathrm{HCO}_{3}{ }^{-}$ratios illustrate the predominant role of carbonate weathering on the riverine $\mathrm{HCO}_{3}{ }^{-}$, even for catchments where silicate rocks are dominant. In contrast, a cascade of dams in WJ tributary influenced the concentrations of DSi and $\mathrm{HCO}_{3}^{-}$and resulted in a positive correlation between DSi and $\mathrm{HCO}_{3}^{-}$. This is because reservoirs allowed populations of diatoms to develop and diatoms stoichiometrically sequestered DSi and $\mathrm{HCO}_{3}^{-}$causing a negative feedback regulation on the DSi:HCO ${ }_{3}^{-}$ ratio. Our study demonstrates that the relationship between DSi and $\mathrm{HCO}_{3}^{-}$can reflect not only their geological background but also the influence of algal activity (diatom uptake) within rivers.
\end{abstract}

Key words: chemical weathering, dam effect, diatoms, negative regulation, Changjiang river.

Received: January 2013. Accepted: April 2013.

\section{INTRODUCTION}

Continental minerals comprise elements in different stoichiometric ratios. This is the basis of using riverine dissolved solutes to understand mineral chemical weathering. Dissolved silicon (DSi) only originates from silicate weathering, while bicarbonate $\left(\mathrm{HCO}_{3}^{-}\right)$is mainly derived from weathering of silicate and carbonate (Berner et al., 1983; Berner, 1992; Gaillardet et al., 1999; Mortatti and Probst, 2003). Therefore, the critical stoichiometric ratio of $\mathrm{DSi}$ to $\mathrm{HCO}_{3}{ }^{-}$is predictable for a river with a certain geological background.

River is an important passage for transporting matter from land to sea. Human activities such as damming influence riverine transport function. With the increase of dam construction, primal rivers evolve into impounded rivers. Phytoplankton is often the main primary producer in impounded rivers. Algae assimilate nutrient elements from their habitats in characteristic stoichiometric ratios (Sterner and Elser, 2002) and the elemental composition of a phytoplankton assemblage depends on their species composition (Quigg et al., 2003).

Diatoms are one of the most important algal groups in rivers and have an obligate requirement for silicon as their cell wall contains this element. The average ratio of silicon to carbon is 0.79 for freshwater diatoms (Sicko-Goad et al., 1984) and 0.13 for marine diatoms (Brzezinski, 1985). Diatom elemental stoichiometry links the biogeochemical cycles of $\mathrm{Si}$ and carbon $(\mathrm{C})$ and thus the water ratio of $\mathrm{DSi}$ to $\mathrm{HCO}_{3}^{-}$will be influenced by diatom uptake of DSi and dissolved inorganic carbon (DIC). Furthermore, the widespread construction of dams has changed riverine aquatic ecosystems (Conley et al., 1993; Humborg et al., 1997; Wang et al., 2008) and increased the potential for phytoplankton growth, consequently increasing their potential effect on elemental geochemical cycles.

Although the $\mathrm{Si}$ and $\mathrm{C}$ cycles are linked biologically and geochemically in river-reservoir systems, so far little attention has been paid to the $\mathrm{Si} C \mathrm{C}$ ratio. However, the stoichiometry in rivers of other elements such as $\mathrm{Ca}: \mathrm{Na}$, $\mathrm{K}: \mathrm{Na}$ and $\mathrm{Cl}: \mathrm{Na}$ are widely used as markers of chemical weathering processes (Gaillardet et al., 1999; Han and Liu, 2004; Chetelat et al., 2008). Therefore, in this study we present the hypothesis that DSi and $\mathrm{HCO}_{3}{ }^{-}$are linked in river-reservoir system, this biogeochemical linkage reflecting not only their external geological resource but also the influence of algal activity within the river. 
The Changjiang $(\mathrm{CJ})$ is particularly well suited to verifying our hypothesis because it is one of the largest rivers in the world covering a huge surface area $\left(1.81 \times 10^{6} \mathrm{~km}^{2}\right.$, $19 \%$ of China). The water chemistry of CJ has been studied extensively. The major element chemistry is mainly controlled by rock weathering (mainly carbonates; Gaillardet et al., 1999; Chen et al., 2002), and four major resources (carbonates, silicates, evaporites and agriculture/urban effluents) contribute to the total dissolved solutes (Chetelat et al., 2008). However, the catchments of its tributaries differ in their geology and hence the tributaries differ in chemical composition (Zhang et al., 2003). Its specific $\mathrm{HCO}_{3}{ }^{-}$flux is strongly correlated with the carbonate mineral content of river basin (Cai et $a l ., 2008)$. Its DSi concentration has decreased due to a reduction in suspended sediment loading and increasing diatom consumption following dam construction (Duan et al., 2007). Nowadays more than 50,000 dams have been constructed in CJ basin rivers (Yang et al., 2011) and stoichiometric change of nutrients due to damming has already had a significant effect on ecosystems in the CJ estuary and the East China sea (Gong et al., 2006; Chai et al., 2009).

In the following, we report data on concentrations of $\mathrm{DSi}, \mathrm{HCO}_{3}{ }^{-}$and related chemical and biological variables to understand the relationship between DSi and $\mathrm{HCO}_{3}{ }^{-}$ and the mechanism that controls this relationship in CJ river and its tributaries.

\section{METHODS}

\section{Study areas}

Changjiang river springs from the Qinghai-Tibet plateau and flows $6300 \mathrm{~km}$ to the East China sea, draining an area of $1.8 \times 10^{6} \mathrm{~km}^{2}$ and falling over $5400 \mathrm{~m}$. The CJ basin is usually divided into three well described physiographic provinces (Chetelat et al., 2008). Carbonate rocks are widely spread over the CJ basin and are particularly widespread in the southern part and sub-basin of the Hanshui river; evaporites are mainly present in the upper reach of $\mathrm{CJ}$; and metamorphic rocks mainly underlie the sub-basin of the Ganjiang (GJ) river (Fig. 1B). Ten major tributaries joining the main $\mathrm{CJ}$ channel were studied. The main river receives water from Xiangjiang and Yuanjiang rivers via lake Dongting and from GJ river via lake Poyang. Wujiang (WJ) (mainly dominated by carbonate weathering) and GJ (mainly dominated by silicate weathering) rivers were selected for a specific comparative investigation.

Wujiang is a southern tributary of CJ, with a length of $1037 \mathrm{~km}$ and a drainage area of $8.8 \times 10^{4} \mathrm{~km}^{2}$. It has an average runoff of $53.4 \times 10^{9} \mathrm{~m}^{3}$ per year with a fall of 2124 $\mathrm{m}$ and is the largest river in Guizhou province. The WJ basin is dominated by Permian and Triassic carbonate rocks, which are interbedded with clastic rocks (Han and Liu, 2004). In WJ, a series of reservoirs have been constructed and the river is now a major hydropower source for China's massive West-to-East power transmission project.

Ganjiang river springs from Ganyuandong in the city of Ruijin and flows from south to west to the CJ. The river has a length of $766 \mathrm{~km}$ and a drainage area of $8.1 \times 10^{5} \mathrm{~km}^{2}$ ( $51 \%$ of the Jiangxi province). The GJ river basin mainly overlies metamorphic and igneous rocks such as granite (Li et al., 2007; Chetelat et al., 2008).

\section{Sampling and analytical methods}

The CJ main channel and its largest tributaries (Fig. 1) were sampled in August 2006 using the sampling and analytical methods described in Chetelat et al. (2008). Wujiang river was sampled monthly from July 2007 to June 2008 for the investigation of water chemistry and sampled seasonally in July and October 2007 and in January and April 2008 for the investigation of phytoplankton. The GJ and its tributaries were sampled in May 2009 at 23 stations. Surface water (upper $0.5 \mathrm{~m}$ ) samples were collected. Water profiles were investigated in the reservoirs Hongjiadu (W3), Dongfeng (W7), Wujiangdu (W15), Shangyoujiang (G2), and Wanan (G12 and G13). Water samples for depth profiles were taken with 5 L Niskin bottles. Sampling depths were $0,5,15,30$ and $60 \mathrm{~m}$ in $\mathrm{W} 3, \mathrm{~W} 7$ and $\mathrm{W} 15 ; 0$, $5,15,25$ and $35 \mathrm{~m}$ in $\mathrm{G} 2 ; 0$ and $5 \mathrm{~m}$ in G12; and $0,5,10$ and $20 \mathrm{~m}$ in G13.

Temperature (T), dissolved oxygen, $\mathrm{pH}$ and chlorophyll $a$ (Chl $a$ ) were measured in situ using a calibrated water quality probe (model YSI 6600) in WJ and GJ rivers. Samples for major cation and anion analysis were filtered through $0.45-\mu \mathrm{m}$ Sartorius ${ }^{\circledR}$ cellulose acetate filters (Sartorius, Göttingen, Germany). Samples for cation analysis were acidified to $\mathrm{pH} 2$ with ultrapurified $\mathrm{HNO}_{3}$. Major cations $\left(\mathrm{Ca}^{2+}, \mathrm{Mg}^{2+}, \mathrm{K}^{+}\right.$, and $\left.\mathrm{Na}^{+}\right)$and $\mathrm{Si}$ were analysed by inductively coupled plasma optical emission spectrometry (ICP-OES) with a precision better than 5\%. Anions $\left(\mathrm{SO}_{4}{ }^{2-}, \mathrm{NO}_{3}^{-}\right.$, and $\left.\mathrm{Cl}^{-}\right)$were determined by ionic chromatography Dionex 120 (Dionex, Sunnyvale, CA, USA) with a precision of $5 \%$. Alkalinity was manually titrated with $\mathrm{HCl}$ in the field. Concentrations of $\mathrm{HCO}_{3}{ }^{-}$ and dissolved $\mathrm{CO}_{2}$ were calculated based on alkalinity, $\mathrm{pH}$ and $\mathrm{T}$ field data with constants corrected for temperature and ionic strength (Maberly, 1996; Barth and Veizer, 1999). The ionic strength was calculated from the major ions. A small portion of each sample was stored for measuring total nitrogen (TN) and total phosphorus (TP). Both TN and TP were determined spectrophotometrically (Unico UV-2000; Unicosci, Wanchai, Hong Kong) after alkaline potassium persulfate digestion (EPA, 1988).

One and a half $\mathrm{L}$ of water sample were preserved with Lugol's solution for analysis of phytoplankton in the sea- 


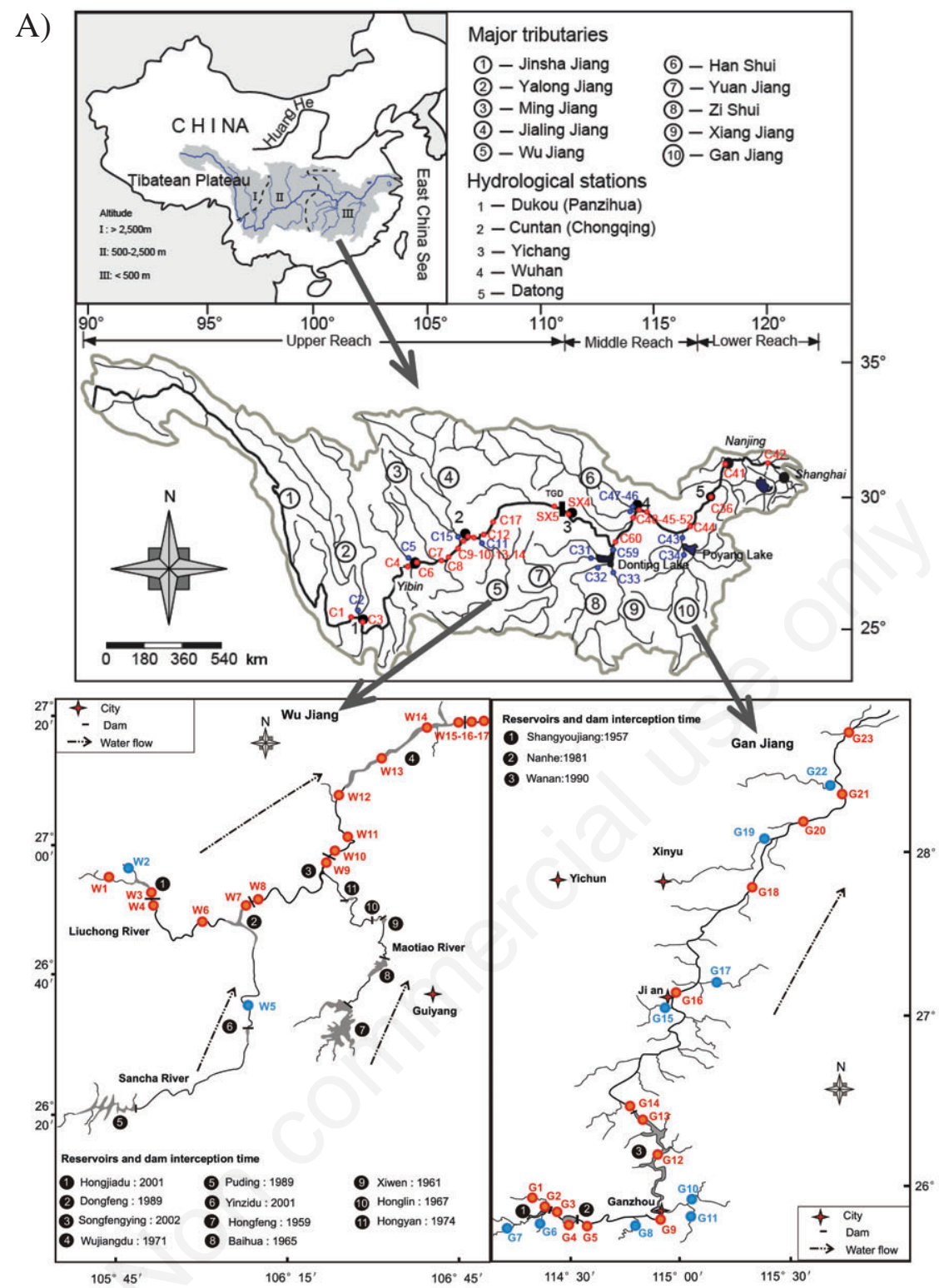

B)

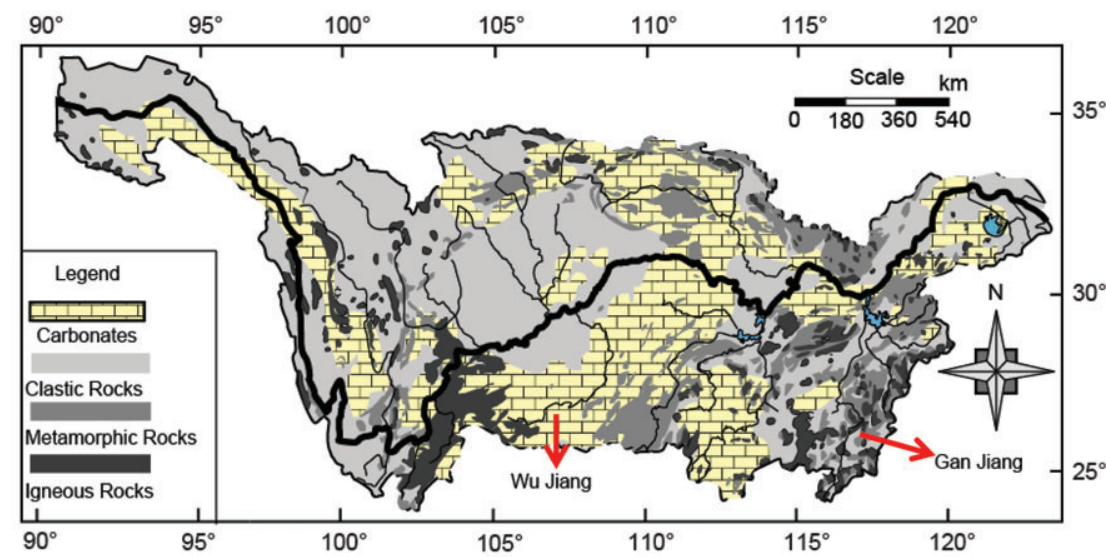

Fig. 1. Map showing sampling numbers and locations (A). Geological maps of the Changjiang basin, modified from Chen et al. (2002) and Li et al. (2007) (B). 
sonal investigation of WJ. The method by Zhang and Huang (1991) was used for taxon identification, counting and cell dimensions using a standard light microscope. The wet weight $\left(\mathrm{mg} \mathrm{L}^{-1}\right)$ of phytoplankton biomass was calculated according to its biovolume and cell density (Zhang and Huang, 1991).

\section{Data collection and statistical analysis}

A long term data of annual mean of $\mathrm{DSi}, \mathrm{HCO}_{3}{ }^{-}$and dissolved $\mathrm{CO}_{2}$ at the hydrological station of Datong near Nanjing were collected by Wang et al. (2007) and integrated by us to increase the dataset for analysis. Pearson's correlation coefficient analyses were carried out with the software SPSS (version 11.5; SPSS Inc., Chicago, IL, USA). Descriptive analyses were carried out with the Minitab 16 statistical software (Minitab Inc., State College, PA, USA). Contour graphs were produced using software Surfer (version 10; Golden Software Inc., Golden, CO, USA).

\section{RESULTS}

\section{Basic physical and chemical properties}

Calcium $\left(\mathrm{Ca}^{2+}\right)$ was the main cation in the rivers of the $\mathrm{CJ}$ basin (Fig. 2). Wujiang river had a higher mean concentration $\left(1504 \mu \mathrm{mol} \mathrm{L}^{-1}\right)$ than CJ $\left(853 \mu \mathrm{mol} \mathrm{L}^{-1}\right)$ and GJ $\left(586 \mu \mathrm{mol} \mathrm{L}^{-1}\right)$. Calcium accounted for 70,52 and $63 \%$ of the total mean cations in WJ, CJ and GJ, respectively. The mean $\mathrm{Ca}^{2+}$ concentration in $\mathrm{CJ}$ was similar to the mean value $\left(808 \mu \mathrm{mol} \mathrm{L}^{-1}\right)$ reported by Chen et al. (2002). Magnesium $\left(\mathrm{Mg}^{2+}\right)$ was another main cation in CJ (mean value of $323 \mu \mathrm{mol} \mathrm{L}^{-1}$ ) and $\mathrm{WJ}$ (mean value of 418 $\mu \mathrm{mol} \mathrm{L}{ }^{-1}$ ), but was lower in GJ (mean value of $85 \mu \mathrm{mol}$ $\left.\mathrm{L}^{-1}\right)$. The concentration of sodium $\left(\mathrm{Na}^{+}\right)$varied widely in CJ, ranging from 94 (Yuanjing at Taoyuan, C31) to 1393 $\mu \mathrm{mol} \mathrm{L}^{-1}$ (Jinshajiang at Panzhihua, C1) (Fig. 2).

Bicarbonate was the main anion in the $\mathrm{CJ}$ basin rivers (Fig. 2). Wujiang river had a mean value $\left(2242 \mu \mathrm{mol} \mathrm{L}^{-1}\right)$ similar to CJ $\left(1857 \mu \mathrm{mol} \mathrm{L}^{-1}\right)$, but the concentration of $\mathrm{HCO}_{3}{ }^{-}$was lower in $\mathrm{GJ}\left(615 \mu \mathrm{mol} \mathrm{L}{ }^{-1}\right)$. Bicarbonate accounted for 66,74 and $64 \%$ of the total mean anions in $\mathrm{WJ}$, $\mathrm{CJ}$ and GJ, respectively. The mean $\mathrm{HCO}_{3}{ }^{-}$concentration in $\mathrm{CJ}$ was similar to the mean value $\left(2110 \mu \mathrm{mol} \mathrm{L}^{-1}\right)$ reported by Chen et al. (2002). Wujiang river had higher concentrations of $\mathrm{SO}_{4}{ }^{2-}$ and $\mathrm{NO}_{3}{ }^{-}$than $\mathrm{CJ}$ and $\mathrm{GJ}$, and this is consistent with the reports of Chen et al. (2002) and Duan et al. (2007). The $\mathrm{Cl}^{-}$concentration in CJ ranged from 30 to 1134 $\mu \mathrm{mol} \mathrm{L} \mathrm{L}^{-1}$ and, like for $\mathrm{Na}^{+}$, was more variable in $\mathrm{CJ}$ than in GJ and WJ. The mean Si concentration in GJ $(157 \mu \mathrm{mol}$ $\left.\mathrm{L}^{-1}\right)$ was similar to that in $\mathrm{CJ}\left(161 \mu \mathrm{mol} \mathrm{L}^{-1}\right)$ and almost three times larger than that in $\mathrm{WJ}\left(56 \mu \mathrm{mol} \mathrm{L}^{-1}\right)$.

The median $\mathrm{pH}$ in $\mathrm{CJ}$ was similar to that in $\mathrm{WJ}$ and a little higher than that in GJ (Fig. 2). Wujiang river showed a larger variation of $\mathrm{Chl} a$ concentration than GJ due to the presence of reservoirs in $\mathrm{WJ}$, some of which were eu- trophic (Wang et al., 2008). There was a very high concentration of dissolved $\mathrm{CO}_{2}\left(1389 \mu \mathrm{mol} \mathrm{L}^{-1}\right)$ in the release water of Wujiangdu reservoir (W16) since release water derived from the deep water next to the dam (W15) and bottom water had a high $\mathrm{CO}_{2}$ concentration due to respiration of organic matter (Wang et al., 2011).

\section{Spatio-temporal variation in chemical constituents in Wujiang tributary}

There was a clear seasonality in concentrations of DSi, $\mathrm{HCO}_{3}{ }^{-}$and $\mathrm{CO}_{2}$ in the surface waters of WJ (Fig. 3). In the reservoirs, the concentration of DSi was low between April and September. During this period, the extent of DSi decrease was related to the age of the reservoir: older reservoirs sequestrated more DSi because they were productive and supported large diatom populations. Therefore, DSi concentration decreased downstream because of the construction of this cascade of reservoirs. Bicarbonate also decreased at the surface of the reservoirs and the decrease was also greater in older reservoirs; nonetheless, the release water (W4, W8, W10 and W16) had high $\mathrm{HCO}_{3}{ }^{-}$concentration. The dissolved $\mathrm{CO}_{2}$ showed a pattern of variation that was similar to $\mathrm{HCO}_{3}{ }^{-}$and this was consistent with the report on the cascade of reservoirs in its tributary - Maotiao river (Wang et al., 2011). Depth profiles of $\mathrm{DSi}, \mathrm{HCO}_{3}{ }^{-}$and $\mathrm{CO}_{2}$ showed a clear chemical stratification from April to September and their concentrations increased with depth in Dongfeng reservoir (Fig. 4). Depth profiles in the reservoirs Hongjiadu and Wujiangdu were similar to Dongfeng reservoir and therefore the profile data are not shown.

\section{Phytoplankton in Wujiang tributary}

There were three main algal groups in WJ: chlorophytes, dinophytes and diatoms. Biomass of diatoms showed a clear spatio-temporal variation and got the highest value in Wujiangdu reservoir in April (Fig. 5A). Phytoplankton species composition and biomass differed from different reservoirs (Fig. 5B) and seasons (Fig. 5C). Chlorophytes and dinophytes were dominant in July, and the contribution of diatoms to the total phytoplankton increased from October (52.3\%) and January (43.9\%) and was greatest in April (78.7\%). Dinophytes were important only in July 2007. The mean value of phytoplankton biomass in different stations ranged from 1.7 (W4) to 14.5 $\mathrm{mg} \mathrm{L}^{-1}$ (W14), and in different season from 1.9 (January) to $8.4 \mathrm{mg} \mathrm{L}^{-1}$ (July). Unsurprisingly, phytoplankton biomass decreased with depth (Fig. 5D).

\section{Spatial variation in Changjiang and Ganjiang rivers}

The concentration of $\mathrm{HCO}_{3}{ }^{-}$in $\mathrm{CJ}$ decreased from upstream $\left(2570 \mu \mathrm{mol} \mathrm{L}^{-1}\right.$ in $\left.\mathrm{C} 1\right)$ to downstream $(1563 \mu \mathrm{mol}$ $\mathrm{L}^{-1}$ in $\mathrm{C} 42$ ) as a result of inflowing tributaries of lower al- 
Tab. 1. Relationships between physical, chemical, and biological variables in Wujiang river in terms of the results of Pearson's correlation coefficient analysis.

\begin{tabular}{|c|c|c|c|c|c|c|c|c|c|c|c|c|}
\hline & $\mathrm{T}$ & $\mathrm{pH}$ & DSi & $\mathrm{HCO}_{3}^{-}$ & $\mathrm{CO}_{2}$ & $\mathrm{TN}$ & $\mathrm{TP}$ & Chl $a$ & DIAT & PHY & CDTP & $\mathrm{Si}: \mathrm{HCO}_{3}^{-}$ \\
\hline $\mathrm{pH}$ & $0.215^{* * *}$ & & & & & & & & & & & \\
\hline DSi & -0.083 & $-0.683^{* * *}$ & & & & & & & & & & \\
\hline $\mathrm{HCO}_{3}^{-}$ & $-0.520^{* * *}$ & $-0.187^{* * * *}$ & $0.109^{*}$ & & & & & & & & & \\
\hline $\mathrm{CO}_{2}$ & -0.089 & $-0.708^{* * *}$ & $0.468^{* * *}$ & $0.153^{* *}$ & & & & & & & & \\
\hline $\mathrm{TN}^{2}$ & $-0.120^{*}$ & $-0.266^{* * *}$ & $0.233^{* * *}$ & $0.109^{*}$ & $0.203^{* * *}$ & & & & & & & \\
\hline TP & -0.113 & 0.017 & $-0.182^{* *}$ & $0.129^{*}$ & $0.129^{*}$ & $-0.142^{*}$ & & & & & & \\
\hline Chl $a$ & $0.388^{* * *}$ & $0.604^{* * *}$ & $-0.559^{* * *}$ & $-0.217^{* * *}$ & $-0.334^{* * *}$ & -0.081 & $0.231^{* * *}$ & & & & & \\
\hline DIAT & 0.137 & $0.369^{* * *}$ & $-0.471^{* * *}$ & $-0.227^{*}$ & $-0.311^{* *}$ & -0.050 & -0.007 & 0.186 & & & & \\
\hline PHY & $0.554^{* * *}$ & $0.564^{* * *}$ & $-0.465^{* * *}$ & $-0.545^{* * *}$ & $-0.287^{* *}$ & 0.110 & $0.243^{*}$ & $0.942^{* * *}$ & $0.327^{* * *}$ & & & \\
\hline CDTP & $-0.413^{* * *}$ & 0.167 & $-0.251^{*}$ & 0.115 & $-0.280^{* *}$ & $-0.246^{*}$ & -0.017 & -0.177 & $0.543^{* * *}$ & -0.189 & & \\
\hline $\mathrm{Si}: \mathrm{HCO}_{3}^{-}$ & 0.038 & $-0.640^{* * * *}$ & $0.961^{* * *}$ & $-0.145^{\text {** }}$ & $0.416^{* * *}$ & $0.201^{* * *}$ & $-0.206^{* * *}$ & $-0.534^{* * * *}$ & $-0.427^{* * *}$ & $-0.398^{* * *}$ & $-0.261^{* *}$ & \\
\hline $\mathrm{Si}: \mathrm{CO}_{2}$ & $0.369^{* * *}$ & $0.637^{* * *}$ & $-0.117^{*}$ & $-0.367^{* * *}$ & $-0.378^{* * *}$ & $-0.153^{* *}$ & -0.080 & $0.508^{* * *}$ & -0.044 & $0.686^{* * *}$ & -0.196 & -0.038 \\
\hline
\end{tabular}

T, temperature; $\mathrm{DSi}$, dissolved sililcon; $\mathrm{HCO}_{3}^{-}$, bicarbonate; $\mathrm{CO}_{2}$, carbon dioxide; TN, total nitrogen; TP, total phosphorus; Chl a, chlorophyll a; DIAT, diatom biomass; PHY, phytoplankton biomass; CDTP, contribution of diatoms to the total phytoplankton; $\mathrm{Si}_{\mathrm{H}} \mathrm{HCO}_{3}^{-}$, ratio between silicon and bicarbonate; $\mathrm{Si}: \mathrm{CO}_{2}$, ratio between silicon and carbon dioxide. ${ }^{*}$ Significance at the 0.05 level (2-tailed); ${ }^{* *}$ significance at the 0.01 level (2-tailed); ${ }^{* * *}$ significance at the 0.001 level (2-tailed).
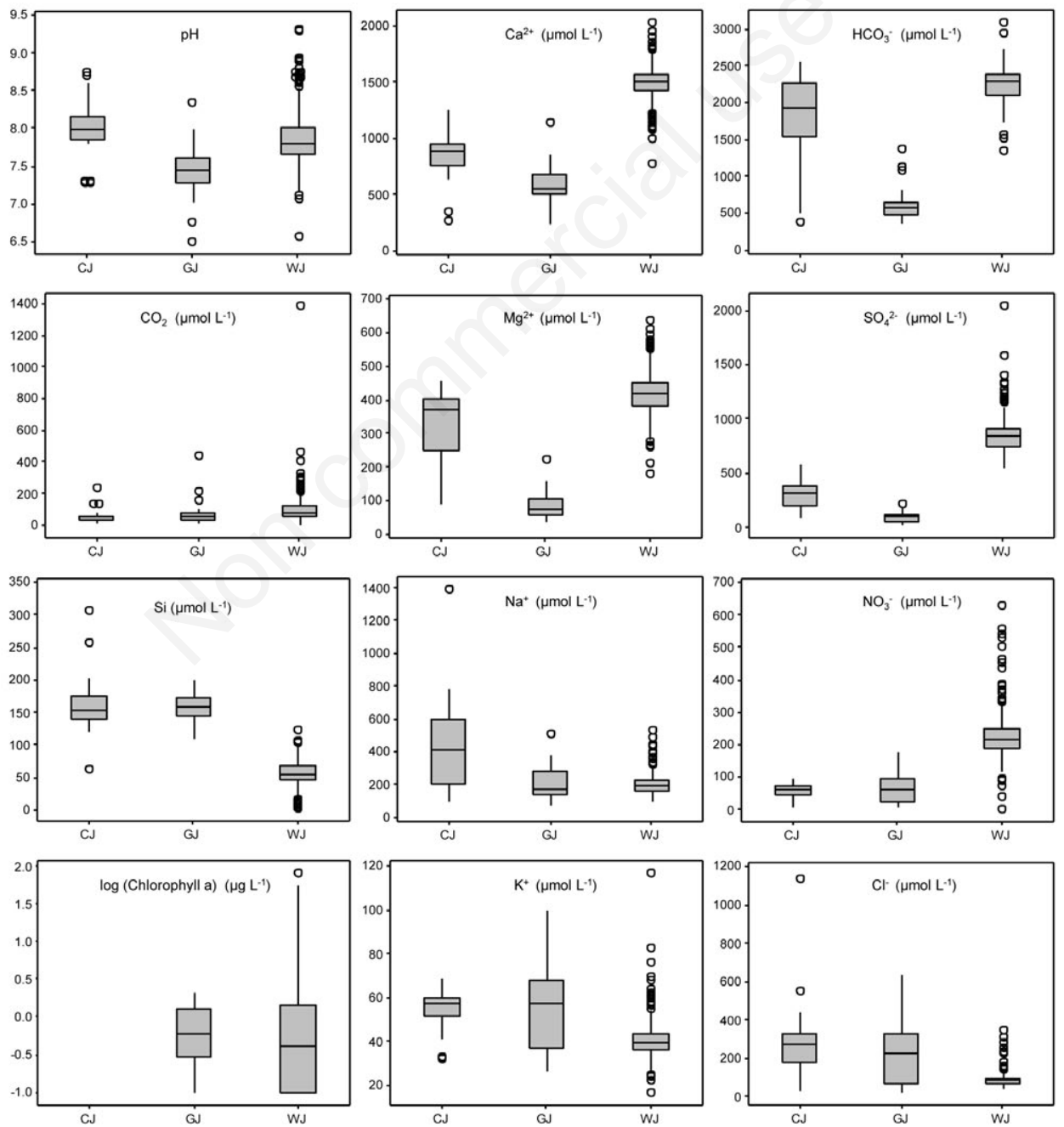

Fig. 2. Box plots of physical, chemical, and biological variables measured in Changjiang (CJ) river and Ganjiang (GJ) and Wujiang (WJ) tributaries. Box boundaries indicate the $25^{\text {th }}$ and $75^{\text {th }}$ percentiles; whiskers extend to a maximum of 1.5 times the inter-quartile range; the inner horizontal line is the median; and circles indicate outliers. 
kalinity. The concentration of dissolved $\mathrm{CO}_{2}$ had a similar pattern of variation to that of $\mathrm{HCO}_{3}^{-}$, but with a smaller amplitude $\left(56 \mu \mathrm{mol} \mathrm{L}^{-1}\right)$ (Fig. 6A). Dissolved silicon increased slightly from upstream to downstream, which was caused by input of DSi from GJ. The Three Gorges reservoir resulted in higher concentrations of $\mathrm{CO}_{2}$ and $\mathrm{HCO}_{3}^{-}$ and lower concentrations of DSi.

In GJ, concentrations of dissolved $\mathrm{CO}_{2}$ and $\mathrm{HCO}_{3}{ }^{-}$ were fairly constant along the main channel except for high values in G5 and G9 (Fig. 6B). These high values may have been caused by bottom waters releasing from Nanhe reservoir and the input of its tributary (G8) with the higher bicarbonate concentrations. The concentration of DSi in GJ decreased slightly downstream.

\section{Long term variation at Datong station}

The concentrations of $\mathrm{Si}$ and dissolved $\mathrm{CO}_{2}$ declined from 1964 to 1984 at the hydrological station of Datong. On the contrary, there was no significant change in the concentration of $\mathrm{HCO}_{3}^{-}$(Fig. 7). The amplitude of $\mathrm{HCO}_{3}{ }^{-}$ $\left(272 \mu \mathrm{mol} \mathrm{L}^{-1}\right)$ was 10 times less than its own concentration, whereas the amplitudes of DSi $\left(61 \mu \mathrm{mol} \mathrm{L}^{-1}\right)$ and $\mathrm{CO}_{2}\left(124 \mu \mathrm{mol} \mathrm{\textrm {L } ^ { - 1 }}\right)$ were comparable, as for magnitude, to their own concentrations.

\section{Relationship analysis}

The concentrations of $\mathrm{Si}$ and $\mathrm{HCO}_{3}^{-}$were significantly negatively correlated in CJ and GJ, but weakly positively correlated in WJ (Fig. 8). This suggests that factors influencing the concentrations of $\mathrm{DSi}$ and $\mathrm{HCO}_{3}^{-}$in WJ were different from the two other rivers. The concentration of DSi was significantly positively correlated with $\mathrm{CO}_{2}$ in WJ, while this was not found in CJ and GJ (Fig. 8).

The $\mathrm{Si}: \mathrm{HCO}_{3}{ }^{-}$ratio in $\mathrm{WJ}$ was significantly negatively correlated with the values of diatoms, Chl $a$ and TP (Tab. 1). This highlights the large effect of biological factors on the $\mathrm{Si}: \mathrm{HCO}_{3}{ }^{-}$ratio in $\mathrm{WJ}$.

\section{DISCUSSION}

\section{Response of dissolved silicon-bicarbonate relationship to geological background}

Rock weathering controls the major element chemistry of CJ. According to chemical and isotopic analysis, carbonate weathering is the main contribution to total dissolved solids (TDS), ranging from 40 to $80 \%$. The contribution of silicate weathering to TDS ranged from 5 to $19.5 \%$ and that of evaporite weathering from 0 to $45 \%$ in CJ (Chetelat et al., 2008). Evaporite weathering was most important in upper CJ but accounted for less than $10 \%$ of TDS in middle and lower CJ. The GJ was dominated by silicate weathering and $\mathrm{WJ}$ by carbonate weathering (Chetelat et al., 2008).
The molar ratio of DSi to $\mathrm{HCO}_{3}^{-}$originating from weathering of a given mineral is predictable. For calcite, one of the main carbonate minerals, this ratio is 0 (eq. 1) and for a silicate mineral plagioclase (Beaulieu et al., 2010), this ratio is 0.67 (eq. 2). Therefore, the $\mathrm{DSi}: \mathrm{HCO}_{3}$ ratio will vary from 0 to 0.67 for the river water chemistry controlled by carbonate and/or silicate weathering.

Our results clearly show that the $\mathrm{Si}: \mathrm{HCO}_{3}{ }^{-}$ratio fluctuates between 0 and 0.67 (Fig. 8), increases with the dominance of silicate weathering, and decreases with the dominance of carbonate weathering.

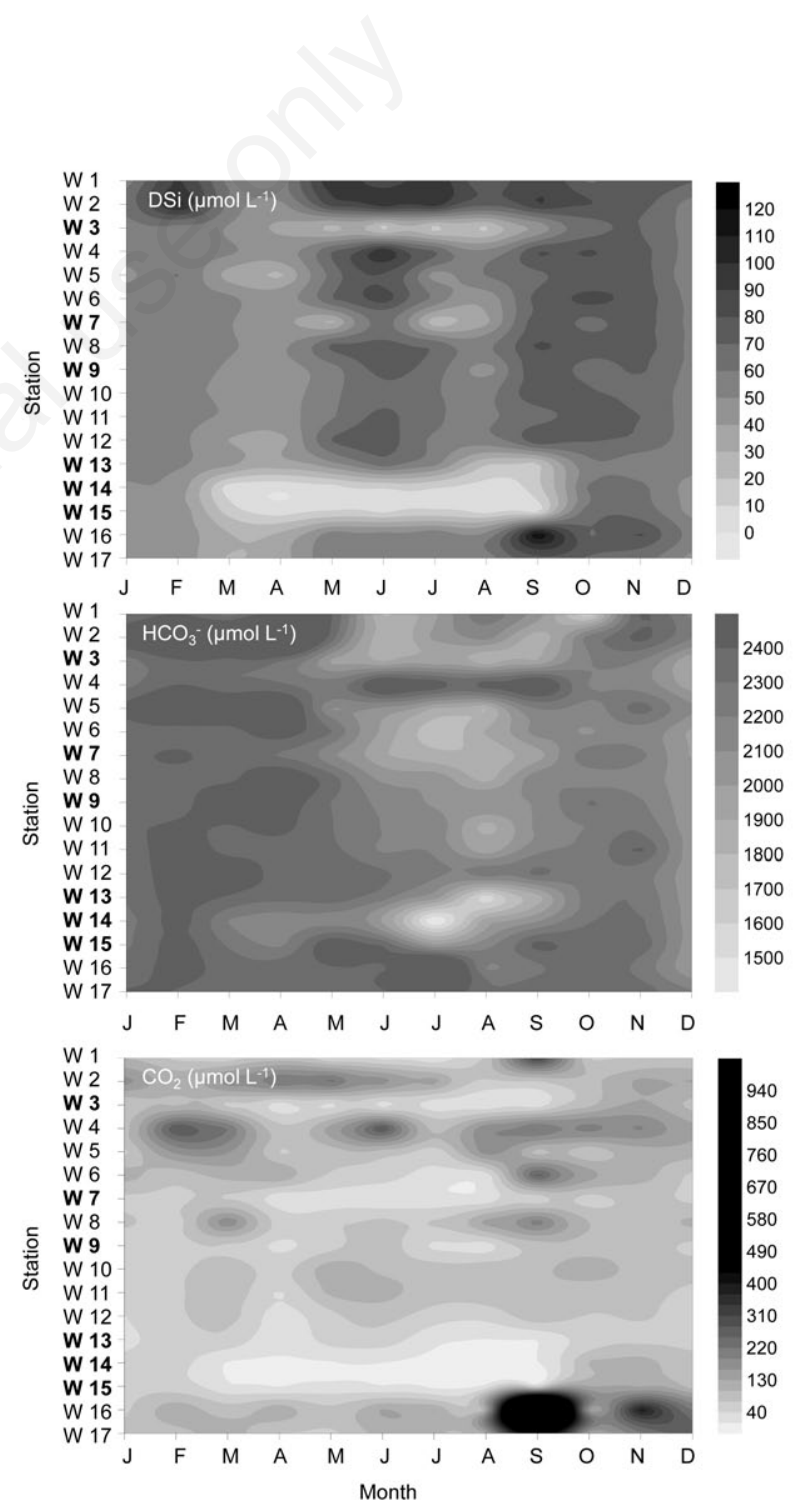

Fig. 3. Spatio-temporal variation of dissolved silicon, bicarbonate, and carbon dioxide of surface waters in Wujiang tributary. Stations are listed one after the other and stations from reservoirs are in bold. 
$\mathrm{CaCO}_{3}+\mathrm{CO}_{2}+\mathrm{H}_{2} \mathrm{O} \rightarrow \mathrm{Ca}^{2+}+2 \mathrm{HCO}_{3}^{-}$

$4 \mathrm{Na}_{05} \mathrm{Ca}_{05} \mathrm{Al}_{15} \mathrm{Si}_{25} \mathrm{O}_{8}+17 \mathrm{H}_{2} \mathrm{O}+6 \mathrm{CO}_{2} \rightarrow$ $3 \mathrm{Al}_{2} \mathrm{Si}_{2} \mathrm{O}_{5}(\mathrm{HO})_{4}+2 \mathrm{Na}^{+}+2 \mathrm{Ca}^{2+}+6 \mathrm{HCO}_{3}^{-}+4 \mathrm{H}_{4} \mathrm{SiO}_{4}$

The rate of carbonate weathering is 100 times greater than that of silicate weathering (Plummer et al., 1978; Liu and Dreybrodt, 1997; Kump et al., 2000). River water controlled by carbonate rock weathering will contain high $\mathrm{HCO}_{3}{ }^{-}$and low DSi concentrations, whereas river water controlled by silicate rock weathering will contain low $\mathrm{HCO}_{3}{ }^{-}$and high DSi concentrations. In addition, the inhomogeneous distributions of silicate and carbonate rocks finally resulted in a significant negative relationship between $\mathrm{HCO}_{3}{ }^{-}$and $\mathrm{Si}$ in $\mathrm{CJ}$ (Fig. 8). According to equation 2 , it is expected to find a positive relationship between
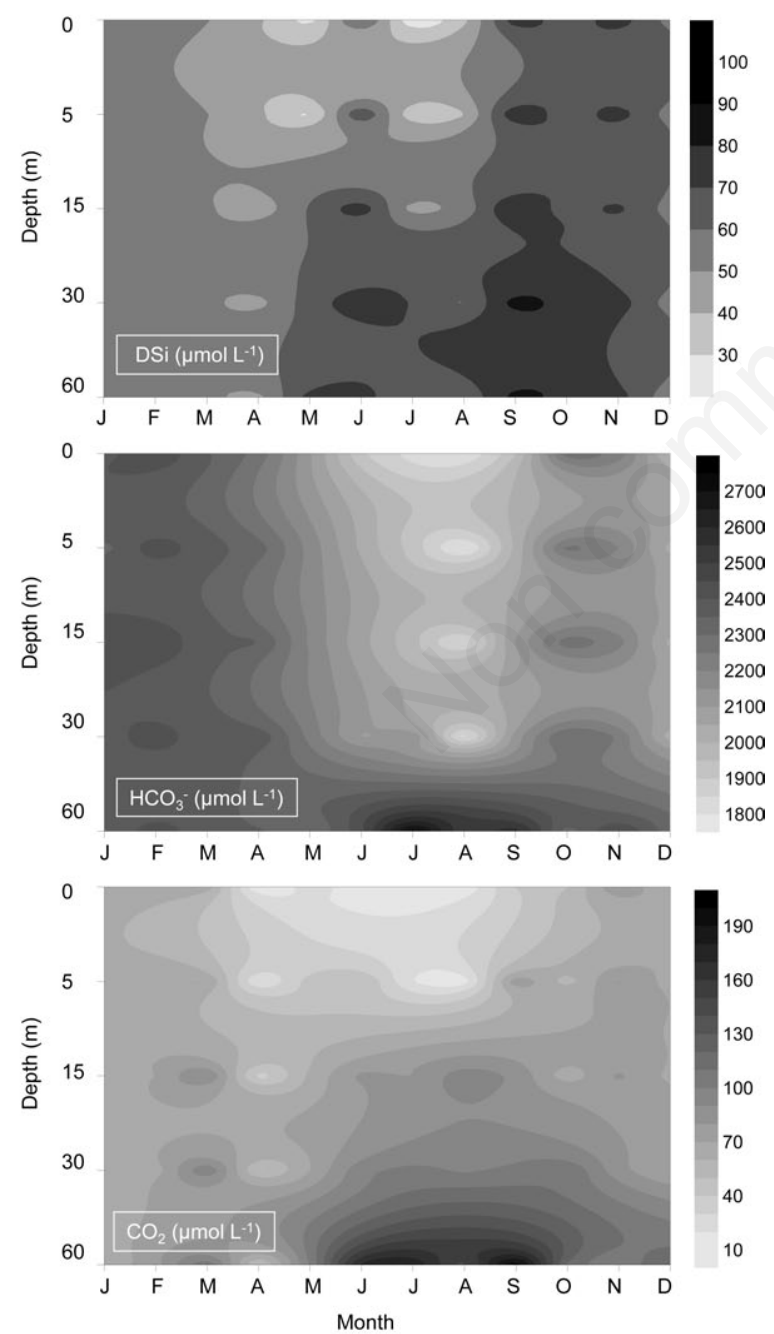

Fig. 4. Monthly profiles of dissolved silicon, bicarbonate, and carbon dioxide in Dongfeng reservoir on Wujiang tributary.
$\mathrm{HCO}_{3}{ }^{-}$and DSi in a catchment dominated by silicate rock weathering. However, an inverse relationship between $\mathrm{HCO}_{3}{ }^{-}$and DSi was found and the DSi: $\mathrm{HCO}_{3}{ }^{-}$ratios deviated from 0.67 in GJ (Fig. 8), suggesting that, even in a catchment controlled by silicate weathering, $\mathrm{HCO}_{3}^{-}$was still mainly derived from trace amounts of bedrock carbonate, this last being unevenly distributed in the river basin. This conclusion is consistent with other studies showing that $1 \%$ carbonate in the bedrock contributed to $82 \% \mathrm{HCO}_{3}{ }^{-}$flux in the major Himalayan rivers (Blum et al., 1998; Jacobson et al., 2002). As for a catchment dominated by carbonate rock weathering, because DSi only originates from silicate rocks and these minor silicate rocks unevenly inlay carbonate rocks, a negative relationship between $\mathrm{HCO}_{3}^{-}$and DSi is also expected. However, this expectation was not found in WJ (Fig. 8). The DSi-
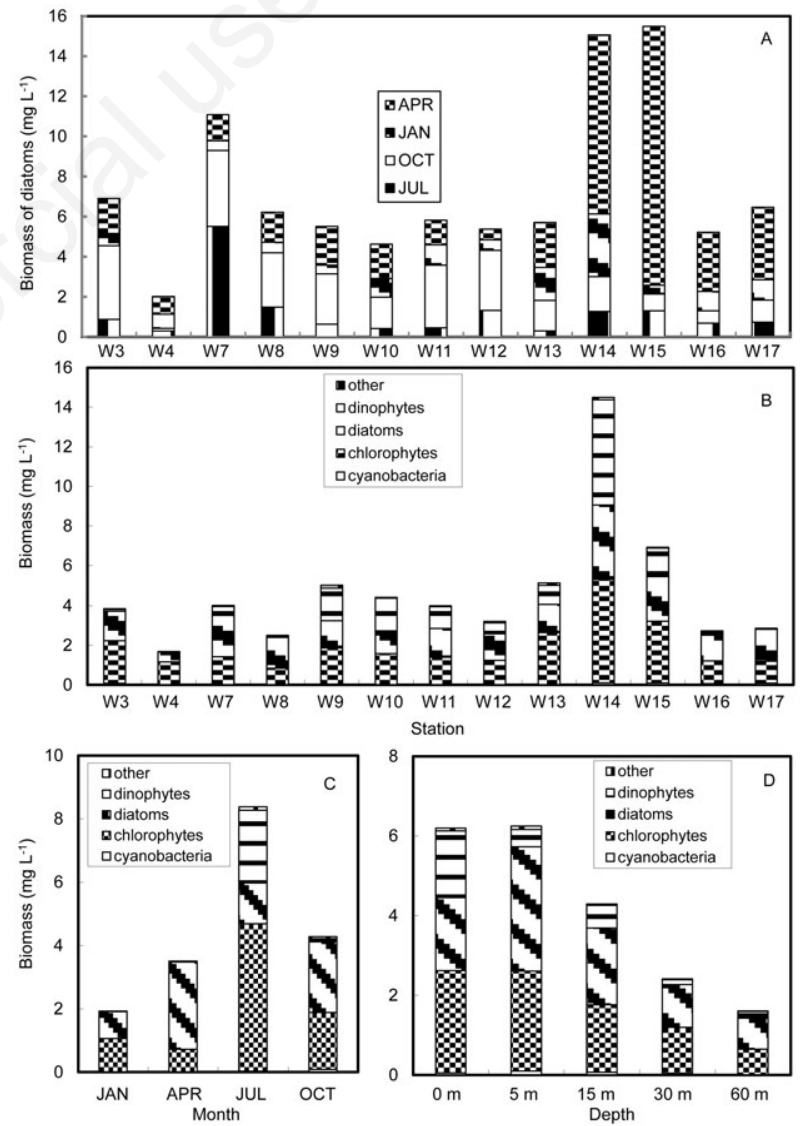

Fig. 5. Phytoplankton species composition and biomass in $\mathrm{Wu}-$ jiang tributary. Spatio-temporal variation of diatoms (A), mean phytoplankton species composition in different stations (B), seasons (C) and depths (D). 
$\mathrm{HCO}_{3}{ }^{-}$relationship in the reservoir waters showed significant difference from that in the river waters (Fig. 9), and only DSi and $\mathrm{HCO}_{3}{ }^{-}$of river waters in WJ (Fig. 9B) showed similar relationship to that in CJ and GJ (Fig. 8). The strong involvement of biological activity modified the $\mathrm{DSi}-\mathrm{HCO}_{3}{ }^{-}$relationship and therefore positive relationships between $\mathrm{HCO}_{3}{ }^{-}$and $\mathrm{DSi}$ and between $\mathrm{CO}_{2}$ and DSi were found for the total dataset of WJ (Tab. 1).

\section{Regulation of dissolved silicon-bicarbonate relationship by diatom uptake}

A riverine heterotrophic ecosystem may be transformed into an autotrophic one after damming a river to produce a reservoir (Wetzel, 2001). Phosphorus was the

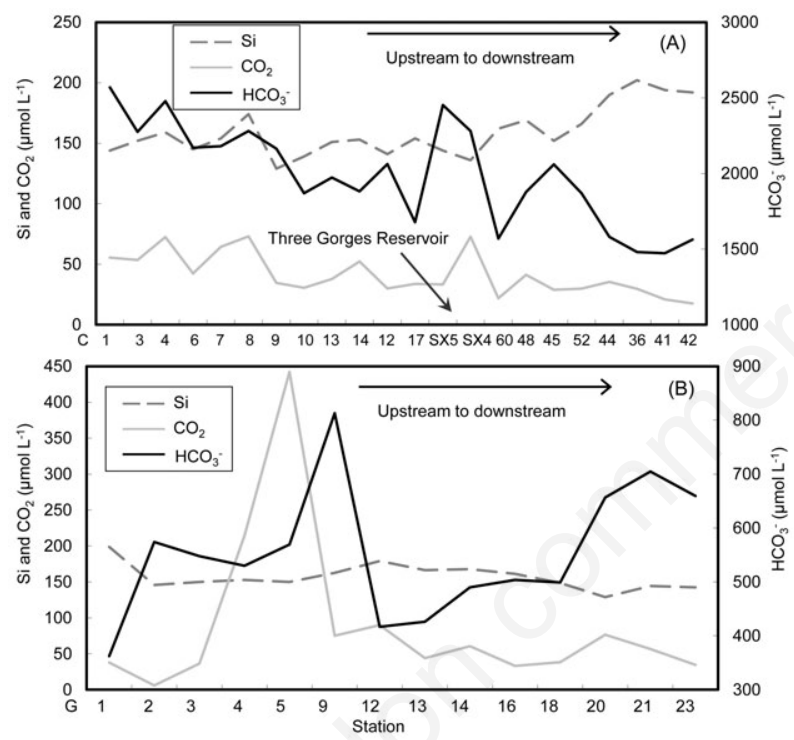

Fig. 6. Variation of silicon, bicarbonate, and carbon dioxide in the Changjiang main channel (A) and the Ganjiang main channel (B) from upstream to downstream.

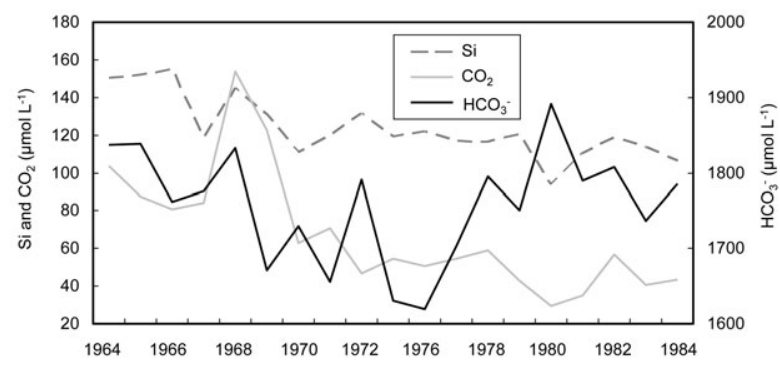

Fig. 7. Variations of annual mean of silicon, bicarbonate, and carbon dioxide at Datong station near Nanjing from 1964 to 1984. Data were collected by Wang et al. (2007). main factor limiting algal growth because Chl $a$ and phytoplankton biomass were significantly correlated with the concentration of TP (Tab. 1). Diatoms are an important group of phytoplankton (Fig. 5). According to the correlation analysis, DSi and $\mathrm{CO}_{2}$ were stoichiometrically assimilated by diatoms and this led to the significant positive correlation between $\mathrm{DSi}$ and $\mathrm{CO}_{2}$ in WJ's reservoirs (Fig. 9A). The dissolved $\mathrm{CO}_{2}$ in these reservoirs can only come from the conversion of $\mathrm{HCO}_{3}{ }^{-}$in place of the atmosphere because the partial pressure of $\mathrm{CO}_{2}$ in river is much higher than that in atmosphere (Wang et al., 2007, and references therein). Uptake of $\mathrm{CO}_{2}$ by algae finally induced the decrease of $\mathrm{HCO}_{3}{ }^{-}$and this caused $\mathrm{HCO}_{3}{ }^{-}$to be strongly positively correlated to DSi in WJ's reservoirs. After regulation by diatom uptake, the relationship be-
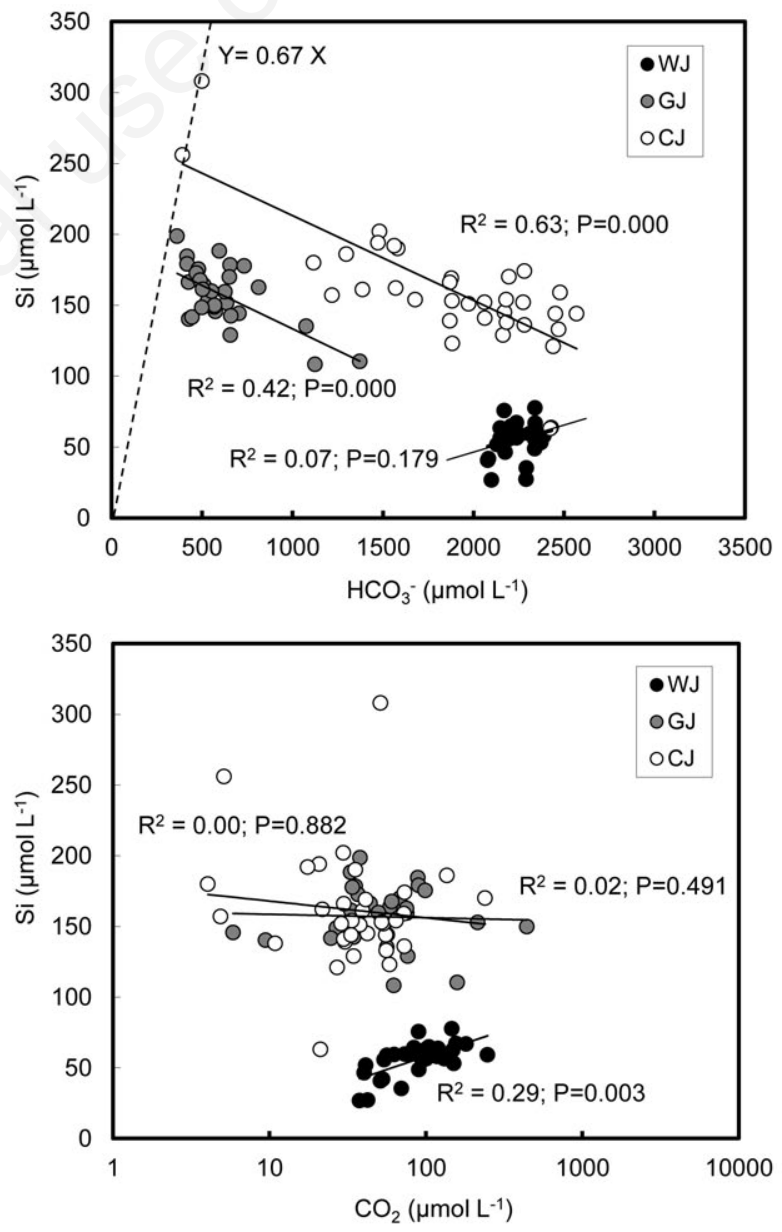

Fig. 8. Scatter plots of silicon $v s$ bicarbonate and silicon $v s$ carbon dioxide in Changjiang (CJ), Ganjiang (GJ) and Wujiang (WJ) rivers. Data from WJ are the monthly mean of different stations including different depths. The line $\mathrm{Y}=0.67 \mathrm{X}$ is based on the plagioclase weathering (eq. 2). 
tween $\mathrm{DSi}$ and $\mathrm{HCO}_{3}^{-}$in the downstream river waters became different from that in the upstream ones (Fig. 9B). Therefore, the regulation by diatoms clearly changed the negative correlation between $\mathrm{DSi}$ and $\mathrm{HCO}_{3}{ }^{-}$that was controlled by geological background.

The concentration of DSi was an order of magnitude similar to $\mathrm{CO}_{2}$ concentration but both were about 10 times smaller than $\mathrm{HCO}_{3}^{-}$concentration. Variation in the $\mathrm{Si}: \mathrm{HCO}_{3}{ }^{-}$ratio was more dependent on variation of $\mathrm{DSi}$ compared with $\mathrm{HCO}_{3}^{-}$, whereas the $\mathrm{Si}: \mathrm{CO}_{2}$ ratio was more dependent on variation of $\mathrm{CO}_{2}$ compared with DSi according to the correlation analysis. Therefore, the $\mathrm{Si}: \mathrm{HCO}_{3}{ }^{-}$ratio showed a different correlation with the related variables from the $\mathrm{Si}: \mathrm{CO}_{2}$ ratio.

The $\mathrm{Si}: \mathrm{HCO}_{3}{ }^{-}$ratio decreased with the abundance of diatoms, Chl $a$ and TP (Fig. 10) because Si and C are needed for diatom growth, and the mean $\mathrm{Si}: \mathrm{C}$ ratio of freshwater diatoms (0.79; Sicko-Goad et al., 1984) was larger than the $\mathrm{Si}: \mathrm{HCO}_{3}{ }^{-}$ratio of the river waters $(<0.67)$. This is a negative feedback regulation. The $\mathrm{Si}: \mathrm{HCO}_{3}{ }^{-}$ratio also showed a significant negative correlation with the contribution of diatoms to the total phytoplankton (Tab. 1). This relationship means that the increase of non-diatom phytoplankton will tend to increase the $\mathrm{Si}: \mathrm{HCO}_{3}{ }^{-}$ratio because non diatoms only assimilate DIC but not DSi. Therefore, the $\mathrm{Si}: \mathrm{HCO}_{3}{ }^{-}$ratio can also respond to changes of algal species composition.

The spatial snapshot of DSi did not show a large fluctuation in CJ and GJ (Fig. 6). However, long term data showed a clear decrease in its concentration in Datong (Fig. 7) and, obviously, the $\mathrm{Si}: \mathrm{HCO}_{3}{ }^{-}$ratio decreased with time as a response, indicating the occurrence of the regulation by diatom uptake. Although the bottom releasing water of the reservoirs can cause the increase of DSi in release waters, the net transport downstream for DSi through the reservoirs is negative because there is still a part of biological silicon staying in the sediments. This is the reason why DSi concentration decreased with time in Datong (Fig. 7). The decreasing tendency of silicon was also reported in middle and lower CJ (Duan et al., 2007)
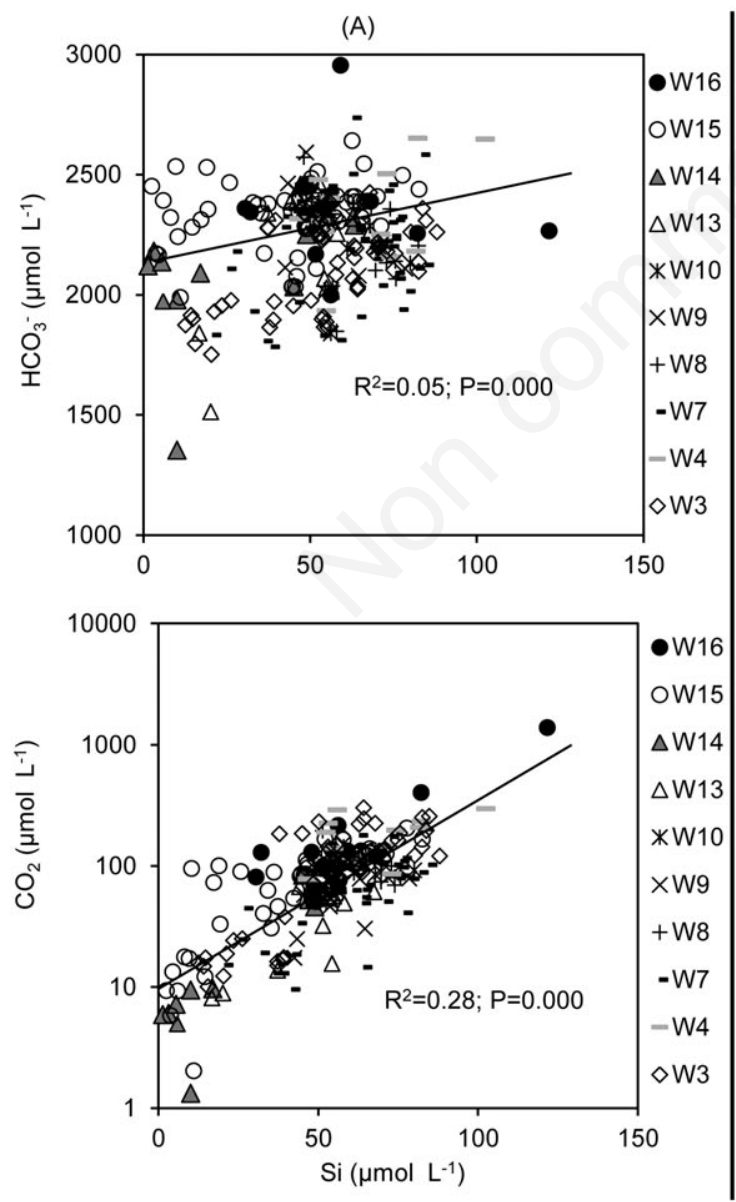

(B)
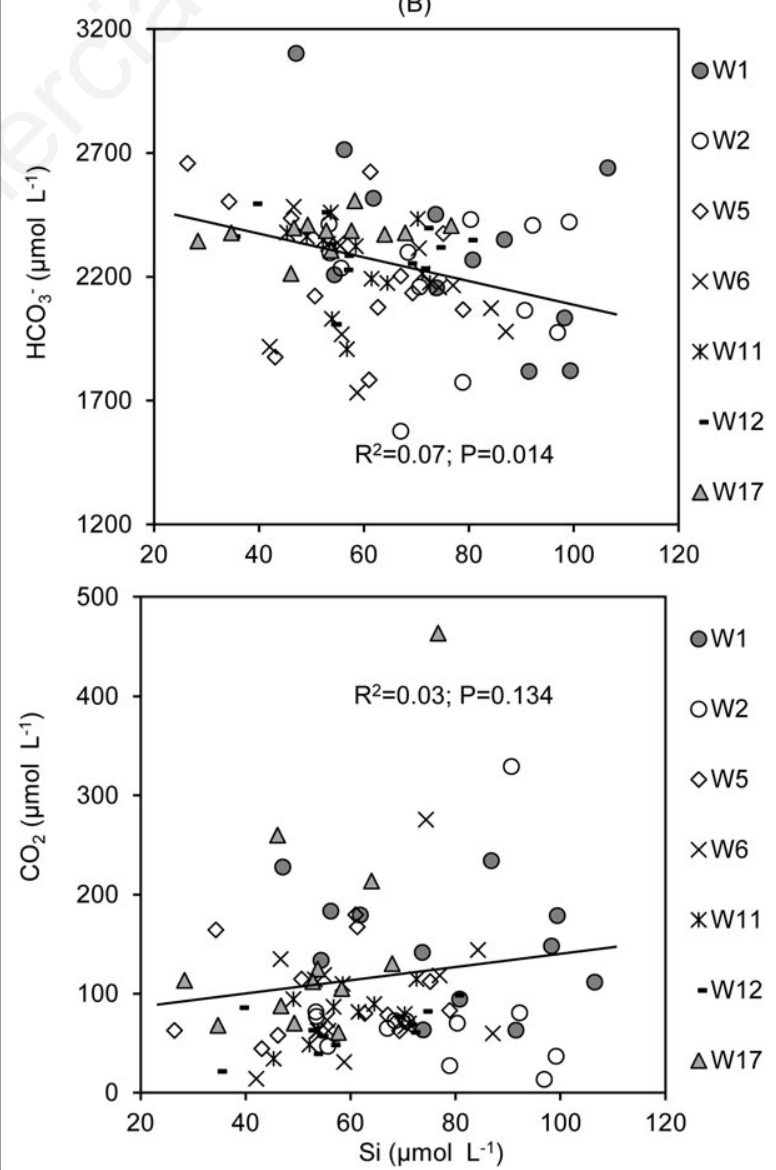

Fig. 9. Scatter plots of silicon vs bicarbonate and silicon $v s$ carbon dioxide in Wujiang tributary. Data from reservoir and release waters are shown in (A), while data from river waters are in $(\mathrm{B})$. 

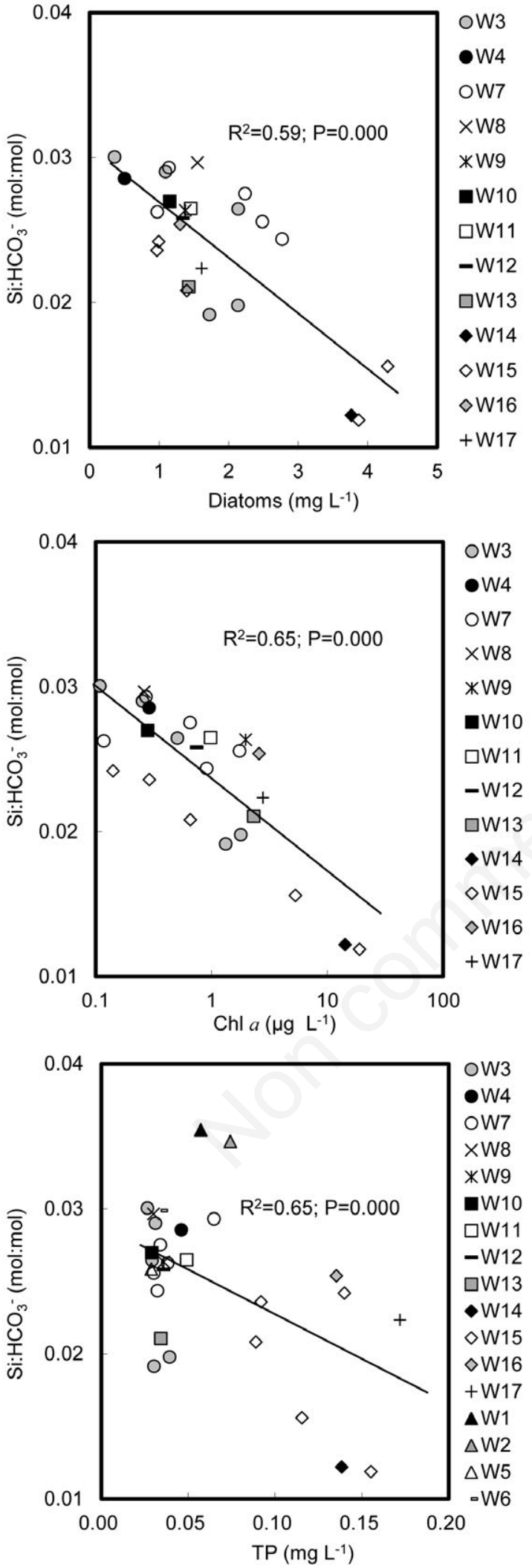

Fig. 10. Scatter plots of mean $\mathrm{Si}: \mathrm{HCO}_{3}^{-}$ratio $v s$ mean diatom biomass, Chlorophyll $a$ and total phosphorus, respectively, in different stations. in a long term. This suggested that the regulation by diatom uptake can be inconspicuous in a spatial snapshot on a large scale, but the cumulative effect of this regulation with time cannot be ignored.

\section{CONCLUSIONS}

The concentrations of DSi and $\mathrm{HCO}_{3}^{-}$in the $\mathrm{CJ}$ basin rivers were related to their geological origin. The $\mathrm{DSi}: \mathrm{HCO}_{3}{ }^{-}$ratio ranged from 0 to 0.67 , increased when silicate weathering dominated, and decreased when carbonate and/or evaporite weathering prevailed. Damming induced the increasing effect of algal activity on the elemental geochemical cycle, and diatom uptake could synchronously sequester $\mathrm{DSi}$ and $\mathrm{CO}_{2}$ (from $\mathrm{HCO}_{3}^{-}$) via the mean stoichiometric ratio of 0.79 , thus having a negative feedback regulation on the $\mathrm{DSi}: \mathrm{HCO}_{3}{ }^{-}$ratio. Our study demonstrated that the relationship between DSi and $\mathrm{HCO}_{3}{ }^{-}$can reflect not only their geological background but also the influence of algal activity within rivers.

\section{ACKNOWLEDGMENTS}

We are grateful to Siliang Li, Jun Li and Xiaolong Liu for assistance in sample collection in the field, and Anzhi Dang for assistance with phytoplankton analyses. This study was financially supported by the Foundation of Chinese Academy of Sciences (Grant Nos: kzcx2-ew-102 and kzcx2-yw-137), the National Natural Science Foundation of China (Grant No. 41021062, 41130536 and 41210004), and the State Key Laboratory of Environmental Geochemistry.

\section{REFERENCES}

Barth JAC, Veizer J, 1999. Carbon cycle in St. Lawrence aquatic ecosystems at Cornwall (Ontario), Canada: seasonal and spatial variations. Chem. Geol. 159:107-128.

Beaulieu E, Goddéris Y, Labat D, Roelandt C, Oliva P, Guerrero $\mathrm{B}, 2010$. Impact of atmospheric $\mathrm{CO}_{2}$ levels on continental silicate weathering. Geochem. Geophy. Geosy. 11:Q07007.

Berner RA, 1992. Weathering, plants and the long-term carbon cycle. Geochim. Cosmochim. Ac. 56:3225-3231.

Berner RA, Lasaga AC, Garrels RM, 1983. The carbonate-silicate geochemical cycle and its effect on atmospheric carbon-dioxide over the past 100 million years. Am. J. Sci. 283:641-683.

Blum JD, Gazis CA, Jacobson AD, Chamberlain CP, 1998. Carbonate versus silicate weathering in the Raikhot watershed within the High Himalayan Crystalline Series. Geology 26:411-414.

Brzezinski MA, 1985. The Si:C:N ratio of marine diatoms: interspecific variability and the effect of some environmental variables. J. Phycol. 21:347-357.

Cai WJ, Guo X, Chen CTA, Dai M, Zhang L, Zhai W, Lohrenz SE, Yin K, Harrison PJ, Wang Y, 2008. A comparative overview of weathering intensity and $\mathrm{HCO}_{3}^{-}$flux in the world's major rivers with emphasis on the Changjiang, 
Huanghe, Zhujiang (Pearl) and Mississippi Rivers. Cont. Shelf. Res. 28:1538-1549.

Chai C, Yu Z, Shen Z, Song X, Cao X, Yao Y, 2009. Nutrient characteristics in the Yangtze River Estuary and the adjacent East China Sea before and after impoundment of the Three Gorges Dam. Sci. Total. Environ. 407:4687-4695.

Chen J, Wang F, Xia X, Zhang L, 2002. Major element chemistry of the Changjiang (Yangtze River). Chem. Geol. 187:231-255.

Chetelat B, Liu CQ, Zhao ZQ, Wang QL, Li SL, Li J, Wang B, 2008. Geochemistry of the dissolved load of the Changjiang Basin rivers: anthropogenic impacts and chemical weathering. Geochim. Cosmochim. Ac. 72:4254-4277.

Conley DJ, Schelske CL, Stoermer EF, 1993. Modification of the biogeochemical cycle of silica with eutrophication. Mar. Ecol.-Prog. Ser. 101:179-192.

Duan S, Xu F, Wang LJ, 2007. Long-term changes in nutrient concentrations of the Changjiang River and principal tributaries. Biogeochemistry 85:215-234.

EPA, 1988. Environmental quality standard for surface water. State standard of the People's Republic of China (GB 383888). Environmental Protection Administration of China. China Environmental Science Press, Beijing.

Gaillardet J, Dupre B, Louvat P, Allegre CJ, 1999. Global silicate weathering and $\mathrm{CO}_{2}$ consumption rates deduced from the chemistry of large rivers. Chem. Geol. 159:3-30.

Gong GC, Chang J, Chiang KP, Hsiung TM, Hung CC, Duan SW, Codispoti L, 2006. Reduction of primary production and changing of nutrient ratio in the East China Sea: effect of the Three Gorges Dam? Geophys. Res. Lett. 33:L07610.

Han G, Liu CQ, 2004. Water geochemistry controlled by carbonate dissolution: a study of the river waters draining karstdominated terrain, Guizhou Province, China. Chem. Geol. 204:1-21.

Humborg C, Ittekkot V, Cociasu A, Bodungen BV, 1997. Effect of Danube river dam on Black Sea biogeochemistry and ecosystem structure. Nature 386:385-388.

Jacobson AD, Blum JD, Chamberlain CP, Poage M, Sloan VF, 2002. The $\mathrm{Ca} / \mathrm{Sr}$ and $\mathrm{Sr}$ isotope systematics of a Himalayan glacial chronosequence: carbonate versus silicate weathering rates as a function of landscape surface age. Geochim. Cosmochim. Ac. 66:13-27.

Kump LR, Brantley SL, Arthur MA, 2000. Chemical weathering, atmospheric $\mathrm{CO}_{2}$, and climate. Annu. Rev. Earth. Pl. Sc. 28:611-667.

Li M, Xu K, Watanabe M, Chen Z, 2007. Long-term variations in dissolved silicate, nitrogen, and phosphorus flux from the Yangtze River into the East China Sea and impacts on estuarine ecosystem. Estuar. Coast. Shelf S. 71:3-12.
Liu Z, Dreybrodt W, 1997. Dissolution kinetics of calcium carbonate minerals in $\mathrm{H}_{2} \mathrm{O}-\mathrm{CO}_{2}$ solutions in turbulent flow: the role of the diffusion boundary layer and the slow reaction $\mathrm{H}_{2} \mathrm{O}+\mathrm{CO}_{2} \leftrightarrow \mathrm{H}^{+}+\mathrm{HCO}_{3}^{-}$. Geochim. Cosmochim. Ac. 61:2879-2889.

Maberly SC, 1996. Diel, episodic and seasonal changes in $\mathrm{pH}$ and concentration of inorganic carbon in a productive lake. Freshwater Biol. 35:579-598.

Mortatti J, Probst JL, 2003. Silicate rock weathering and atmospheric/soil $\mathrm{CO}_{2}$ uptake in the Amazon basin estimated from river water geochemistry: seasonal and spatial variations. Chem. Geol. 197:177-196.

Plummer LN, Wigley TML, Parkhurst DL, 1978. The kinetics of calcite dissolution in $\mathrm{CO}_{2}$-water systems at $5^{\circ} \mathrm{C}$ to $60^{\circ} \mathrm{C}$ and 0.0 to $1.0 \mathrm{~atm} \mathrm{CO}_{2}$. Am. J. Sci. 278:179-216.

Quigg A, Finkel1 ZV, Irwin AJ, Rosenthal Y, Ho TY, Reinfelder JR, Schofield O, Morel FMM, Falkowski PG, 2003. The evolutionary inheritance of elemental stoichiometry in marine phytoplankton. Nature 425:291-294.

Sicko-Goad L, Schelske CL, Stoermer EF, 1984. Estimation of intracellular carbon and silica content of diatoms from natural assemblages using morphometric techniques. Limnol. Oceanogr. 29:1170-1178.

Sterner RW, Elser JJ, 2002. Ecological stoichiometry: the biology of elements from molecules to the biosphere. Princeton University Press, Princeton: 584 pp.

Wang B, Liu CQ, Wang F, Yu Y, Zhang L, 2008. The distributions of autumn picoplankton in relation to environmental factors in the reservoirs along the Wujiang River in Guizhou Province, SW China. Hydrobiologia 598:35-45.

Wang F, Wang B, Liu CQ, Wang Y, Guan J, Liu X, Yu Y, 2011. Carbon dioxide emission from surface water in cascade reservoirs-river system on the Maotiao River, southwest of China. Atmos. Environ. 45:3827-3834.

Wang F, Wang Y, Zhang J, Xu H, Wei X, 2007. Human impact on the historical change of $\mathrm{CO}_{2}$ degassing flux in River Changjiang. Geochem. T. 8:7.

Wetzel RG, 2001. Limnology: lake and river ecosystems. 3rd ed. Academic Press, San Diego: 1006 pp.

Yang SL, Milliman JD, Li P, Xu K, 2011. 50,000 dams later: erosion of the Yangtze River and its delta. Global Planet. Change 75:14-20.

Zhang J, Ren JL, Liu SM, Zhang ZF, Wu Y, Xiong H, Chen HT, 2003. Dissolved aluminum and silica in the Changjiang (Yangtze River): impact of weathering in subcontinental scale. Global Biogeochem. Cy. 17:1077.

Zhang ZS, Huang XF, 1991. [Methods in freshwater plankton study]. [Book in Chinese]. Science Press, Beijing. 